\title{
Spatial distribution of equine seroreagent to Leptospira spp. in Northeastern Brazil
}

\author{
Distribuição espacial de equinos sororreagentes à Leptospira spp. no \\ Nordeste do Brasil
}

\author{
Davidianne de Andrade Morais ${ }^{1}$ (D); Camila de Sousa Bezerra ${ }^{1}$ (D); Denize Monteiro dos Anjos $^{1}$ (iD; \\ Bruno Cesar Nunes $^{1}$ (D); Denise Batista Nogueira ${ }^{1}$ (D); Nebson Fernandes Pequeno ${ }^{2}$ (D); Diego Figueiredo da Costa $^{1}$ (D); \\ Severino Silvano dos Santos Higino ${ }^{1}$ (1); Sérgio Santos Azevedo ${ }^{1}$ (D); Clebert José Alves ${ }^{1}$ (C) \\ ${ }^{1}$ Universidade Federal de Campina Grande, Centro de Saúde e Tecnologia Rural, Laboratório de Doenças Transmissíveis, Patos - PB, Brazil. \\ ${ }^{2}$ Laboratório Veterinária Diagnósticos, Catolé do Rocha, Paraíba, Brazil.
}

\begin{abstract}
Considering the importance of leptospirosis in both equine husbandry and public health, as well as the relevance of knowledge of current serogroup and the small number of studies addressing this disease in equines in Northeastern Brazil, the present study performed a serological survey of Leptospira spp. in a serum bank of 1,267 equines originating from 177 municipalities, located in four states in Northeastern Brazil: Ceará, Rio Grande do Norte, Paraíba and Pernambuco. The microscopic agglutination test (MAT) was used for diagnosis of leptospirosis using 24 serovars as antigens. The frequency of reagent equines was $29.7 \%$ $(376 / 1,267)$, and $68.9 \%(122 / 177)$ of municipalities had at least one positive reaction. The serogroups reagent were Australis (37.2\%), Icterohaemorrhagiae (29.3\%), Tarassovi (9.6\%), Sejroe (5.8\%), Pomona (5.3\%), Grippotyphosa (4.5\%), Pyrogenes (2.4\%), Bataviae (1.9\%), Ballum and Hebdomadis (1.3\%), Mini (0.5\%), Celledoni, Shermani, and Javanica (0.3\% each). There were significant statistical differences regarding sex and age, with a higher frequency in females $(P=0.014)$, and in animals $\geq 6$ years $(P=0.001)$. We concluded that seropositivity to Leptospira spp. is high in equines in Northeastern Brazil, with a predominance of serologic reactions to the Australis serogroup in the border areas between the states, and the Icterohaemorrhagiae serogroup in coastal areas or their vicinity. The high degree of seropositivity found points to the need to implement prophylactic strategies, both intraspecies infection prophylaxis and rodent control. We also recommended avoiding animal crowding and separating animals according to sex and age group during handling.
\end{abstract}

Keywords: Epidemiology. Zoonosis. Bacterium. Spatialization. Animal health.

\section{RESUMO}

Considerando a importância da leptospirose na equinocultura e na saúde pública, bem como a relevância do conhecimento dos sorogrupos circulantes e do pequeno número de estudos realizados sobre esta doença em equinos no Nordeste do Brasil, o presente trabalho foi delineado para realizar um inquérito sorológico de Leptospira spp. em um banco de soros de 1.267 equinos provenientes de 177 municípios distribuídos em quatro estados: Piaui, Ceará, Paraíba e Pernambuco, localizados na região Nordeste do Brasil. Os soros foram examinados com o teste de Soroaglutinação Microscópica (SAM), utilizando uma coleção de 24 sorovares como antígenos. A frequência de equinos reagentes foi de 29,7\% (376 / 1.267) e $68,9 \%$ (122/177) dos municípios que tiveram pelo menos uma reação positiva. Os sorogrupos reagentes foram Australis (37,2\%), Icterohaemorrhagiae (29,3\%), Tarassovi (9,6\%), Sejroe (5,8\%), Pomona (5,3\%), Grippotyphosa (4,5\%), Pyrogenes $(2,4 \%)$, Bataviae (1,9\%), Ballum e Hebdomadis (1,3\%), Mini (0,5\%), Celledoni, Shermani e Javanica (0,3\%). Houve diferenças estatisticamente significantes quanto ao sexo e idade, com maior frequência no sexo feminino $(\mathrm{P}=0,014)$ e no animal com idade $\geq 6$ anos $(\mathrm{P}=0,001)$. Conclui-se que a infecção por Leptospira spp. tem ocorrência significativa em equídeos do Nordeste do Brasil, com predominância de reações para o sorogrupo Australis nas áreas de fronteira entre os estados e para sorogrupo Icterohaemorrhagiae nas áreas litorâneas ou em suas proximidades. O alto grau de soropositividade encontrado aponta para a necessidade da implementação de estratégias profiláticas tanto intraespécies quanto relacionadas ao controle de roedores. Também recomenda-se evitar superlotações de animais em piquetes e manejá-los em grupos de acordo com o sexo e a faixa etária.

Palavras-chave: Epidemiologia. Zoonose. Bactéria. Espacialização. Saúde animal. 
Correspondence to:

Clebert José Alves

Universidade Federal de Campina Grande, Centro de Saúde e Tecnologia Rural, Laboratório de Doenças Transmissíveis Avenida Universitária, s/n, Bairro Santa Cecília CEP: 58708-110, Patos - PB, Brazil

e-mail: clebertja@uol.com.br

Received: October 01, 2019

Approved: January 23, 2020

How to cite: Morais DA, Bezerra CS, Anjos DM, Nunes BC, Nogueira DB, Pequeno NF, Costa DF, Higino SSS, Azevedo SS, Alves CJ. Spatial distribution of equine seroreagent to Leptospira spp. in Northeastern Brazil. Braz J Vet Res Anim Sci. 2019;56(4): e162784. https://doi. org/10.11606/issn.1678-4456.bjvras.2019.162784

\section{Introduction}

Equine breeding is an economic sector that accounts for about 4.18 billion dollars annually (Lima \& Cintra, 2016), producing animals of high breeding value (Coelho \& Oliveira, 2008). However, despite its economic importance, the main use of equids remains agricultural work, mainly cattle handling (Caselani et al., 2012). Highly neglected diseases such as leptospirosis cause losses in horse breeding businesses and endangers public health (Pinna et al., 2008).

According to data from Notification Diseases Information System (SINAN) (Sistema de Informação de Agravos de Notificação, 2018), 66,569 cases of leptospirosis in humans were confirmed in Brazil from 2000 to 2017, of which 18\% $(11,702)$ were in the Northeast region. During this period, 6,365 people died of leptospirosis in Brazil, 24\% $(1,515)$ of them in the Northeastern area, the region with the second highest number of deaths due to leptospirosis, surpassed only by the Southeast region. Equidae are considered important sources of infection for leptospirosis due to their proximity to humans, especially when both share inadequate environmental, infrastructural, and sanitary conditions (Hamond et al., 2012a), in which the agent can spread (Hamond et al., 2012b).

In equines, seroprevalence depends on the geographical location and the existing serogroups of Leptospira spp. (Sellon \& Long, 2007). In this species, the disease is most often asymptomatic and when clinical signs are present, they may be confused with other diseases (Hashimoto et al., 2007; Braga et al., 2011). Leptospirosis can cause reproductive disorders and physical weakness, as well as recurrent uveitis, also called periodic ophthalmia (Braga et al., 2011), and is considered the greatest worldwide cause of blindness in equines (Artiushin et al., 2012).

Serogroups identification in the region helps raise awareness to improve control of the infection. However, there is a lack of studies addressing the situation of leptospirosis in horses in northeastern Brazil. Characterized as a crucial region, this area has specific characteristics to hinder the survival of leptospirosis agent. Specifically, these characteristics include a significant part of its territory in the drought polygon, with a predominance of semiarid climate, caatinga vegetation, shallow and stony soils, variable relief and seasonal rainfall (Araújo, 2011).

The objective of this study was to perform a serological survey of Leptospira spp. in equines in four states of Northeastern Brazil by serology, searching for the predominant serogroups and their spatial distribution.

\section{Material and Methods}

The research was performed using serum bank and a diagnosis database of horses, provided from the Veterinary Laboratory Diagnostics, Ltd., located in the city of Catolé do Rocha, Paraíba state, Northeastern Brazil. The serum bank contained 1,267 samples collected from March to April 2015 in 177 cities from four states in Northeastern Brazil: Ceará (459 samples), Paraíba (478 samples), Pernambuco (77 samples), and Rio Grande do Norte (253 samples) (Figure 1). There were samples of equines from all mesoregions of the states, except for one in Rio Grande do Norte and three in Pernambuco, thus totaling 16 mesoregions distributed among the four states (Table 1).

Sera were obtained from clinically healthy equines, unvaccinated against leptospirosis, aged from six months (to avoid the interference of colostral antibodies) up to 26 years, and included 635 females and 632 males, all destined to be equestrian sport horses.

The presence of anti-Leptospira spp. antibodies was determined by the microscopic agglutination test (MAT) (Organização Mundial de Saúde Animal, 2014), using a collection of 24 antigens: Leptospira biflexa serovars Andamana and Patoc; Leptospira interrogans serovars Australis, Copenhageni, Bataviae, Bratislava, Canicola, Grippotyphosa, Hardjoprajitno, Pomona, Pyrogenes, Icterohaemorrhagiae, Hebdomadis, Wolffi and Butembo; Leptospira borgpeterseni serovars Autumnalis, Castellonis, Hardjobovis Javanica and Tarassovi; Leptospira santarosai serovars Guaricura and Shermani; Leptospira kirschneri serovar Cynopteri; and Leptospira noguchii serovar Panama. The antigens were kindly provided by the Veterinary Bacteriology Laboratory 


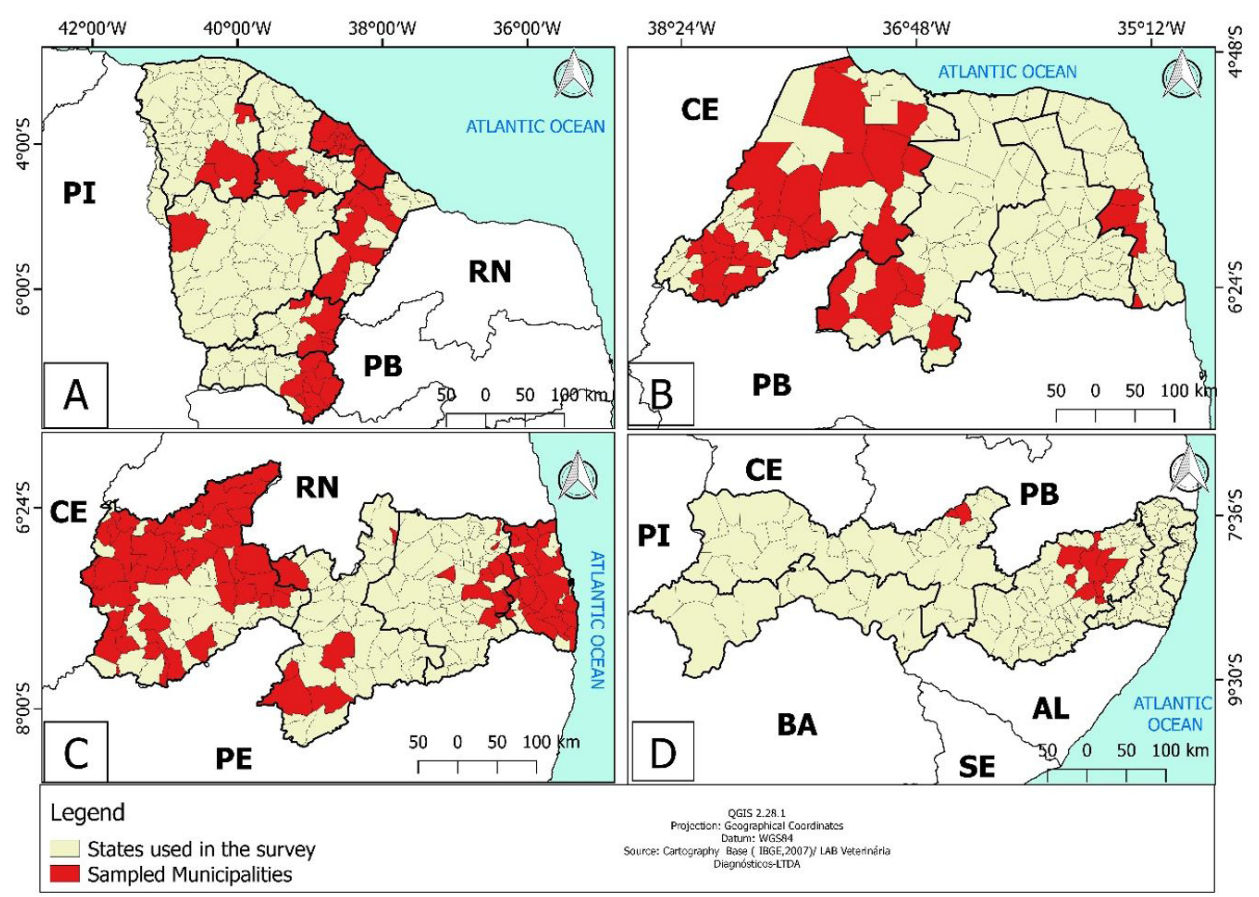

Figure 1 -Spatial distribution of the municipalities participating in the study in the year 2015 in the states of Ceará (A), Rio Grande do Norte (B), Paraíba (C), and Pernambuco (D).

Table 1 - Distribution and frequency of municipalities and equines from the Brazilian Northeast sampled and results of MAT applied to Leptospira sp., grouped by mesoregion, in March and April 2015 - Patos, 2019

\begin{tabular}{|c|c|c|c|c|c|c|c|}
\hline STATE & MESOREGION & $\begin{array}{l}\text { MUNICIPALITIES } \\
\text { SAMPLED }\end{array}$ & $\begin{array}{c}\text { MUNICIPALITIES } \\
\text { WITH } \geq 1 \\
\text { POSITIVE EQUINE (\%) }\end{array}$ & $\begin{array}{c}\text { EQUINES } \\
\text { TESTED }\end{array}$ & $\begin{array}{l}\text { POSITIVE } \\
\text { EQUINES } \\
(\%)\end{array}$ & $\begin{array}{l}\text { PREDOMINANT } \\
\text { SEROGROUP }\end{array}$ & N (\%) \\
\hline CE & CENTRAL-SOUTH & 6 & $5(83)$ & 58 & $13(22)$ & Australis & $6(46)$ \\
\hline CE & JAGUARIBE & 7 & $5(71)$ & 69 & $21(30)$ & Australis & $11(52)$ \\
\hline CE & FORTALEZA M. & 10 & $10(100)$ & 181 & $46(25)$ & Icterohaemorrhagiae & $17(37)$ \\
\hline $\mathrm{CE}$ & NORTHWEST & 3 & $2(67)$ & 8 & $5(62)$ & Australis & $4(80)$ \\
\hline CE & NORTH & 6 & $4(67)$ & 28 & $6(21)$ & Icterohaemorrhagiae & $3(50)$ \\
\hline CE & BACKLANDS & 2 & $1(50)$ & 4 & $1(25)$ & Icterohaemorrhagiae & $1(100)$ \\
\hline CE & SOUTH & 11 & $9(82)$ & 111 & $32(29)$ & Australis & $10(31)$ \\
\hline $\mathrm{RN}$ & CENTRAL & 6 & $1(17)$ & 24 & $3(12)$ & Icterohaemorrhagiae & $2(67)$ \\
\hline $\mathrm{RN}$ & EAST & 4 & $4(100)$ & 23 & $13(56)$ & Australis & $6(46)$ \\
\hline $\mathrm{RN}$ & WEST & 27 & $18(67)$ & 206 & $53(26)$ & Australis & $22(41)$ \\
\hline PB & COUNTRYSIDE & 11 & $4(36)$ & 25 & $9(36)$ & Icterohaemorrhagiae & $3(33)$ \\
\hline PB & BORBOREMA & 5 & $3(60)$ & 9 & $4(44)$ & Australis & $2(50)$ \\
\hline PB & FOREST AREA & 18 & $14(78)$ & 169 & $59(35)$ & Icterohaemorrhagiae & $25(42)$ \\
\hline PB & BACKLANDS & 49 & $35(71)$ & 275 & $89(32)$ & Australis & $34(38)$ \\
\hline \multirow[t]{2}{*}{ PE } & BACKLANDS & 2 & $1(50)$ & 11 & $4(36)$ & Australis & $2(50)$ \\
\hline & TOTAL & 177 & 122 & 1267 & 376 & & \\
\hline
\end{tabular}

$\mathrm{M}=$ metropolitan; $\geq 1=$ At least 1 positive; $\%=$ frequency by mesoregion. $\mathrm{MAT}=$ microscopic agglutination test to leptospirosis; $\mathrm{CE}=\mathrm{Ceará} ; \mathrm{RN}=\mathrm{Rio}$ Grande do Norte, PB = Paraíba; PE = Pernambuco.

of the Federal Fluminense University (UFF) and from the Pasteur Institute, France.

Sera were screened at a dilution of 1:100 and those having $50 \%$ or more agglutination were titrated by the examination of a series of geometric two-fold dilutions. The antibody titer was the reciprocal of the highest dilution that presented a positive result. Antigens were examined under a darkfield microscope prior to testing to verify mobility and check for the presence of autoagglutination or contaminants. For each sample, the most frequent serovar was the one with the highest titer, and results were expressed by serogroups.

The mapping of the municipalities involved in the study and the spatialization of the seropositive equines for leptospirosis were carried out by digital processing of the territories from the municipalities using digital shapes provided by the Brazilian Institute of Geography and Statistics and processed by the QGIS 2.28.1 software.

The comparisons of seropositivity according to age and sex of each animal were performed by association analysis using the 
chi-square test $(\chi 2)$, set at a significance level of $5 \%(P<0.05)$, using the BioEstat software version 5.3 (Ayres et al., 2007).

\section{Results}

Of the 1,267 equine blood serum samples analyzed, $376(29.7 \%)$ reacted positively to MAT and, of the 177 participating cities, 122 (68.9\%) (Table 1) had at least one positive equine (Figure 2 ) with titers $\geq 100$.

The titers ranged from 100 to 800 and the serogroups found were Australis (37.2\%), Icterohaemorrhagiae (29.3\%),
Tarassovi (9.6\%), Sejroe (5.8\%), Pomona (5.3\%), Grippotyphosa (4.5\%), Pyrogenes (2.4\%), Bataviae (1.9\%), Ballum and Hebdomadis (1.3\%), Mini (0.5\%), Celledoni, Shermani, and Javanica (each $0.3 \%$ ) (Table 2). Of the 376 positive reactions, $321(85.4 \%)$ were among the 100 and 200 titer group. Among the serogroups tested, there were positive reactions in 14 (74\%) (Table 2 ).

When grouping seropositive equines by state, we observed 124 (27\%) in Ceará; 69 (27.3\%) in Rio Grande do Norte; 161 (33.7\%) in Paraíba, and 22 (28.6\%) in

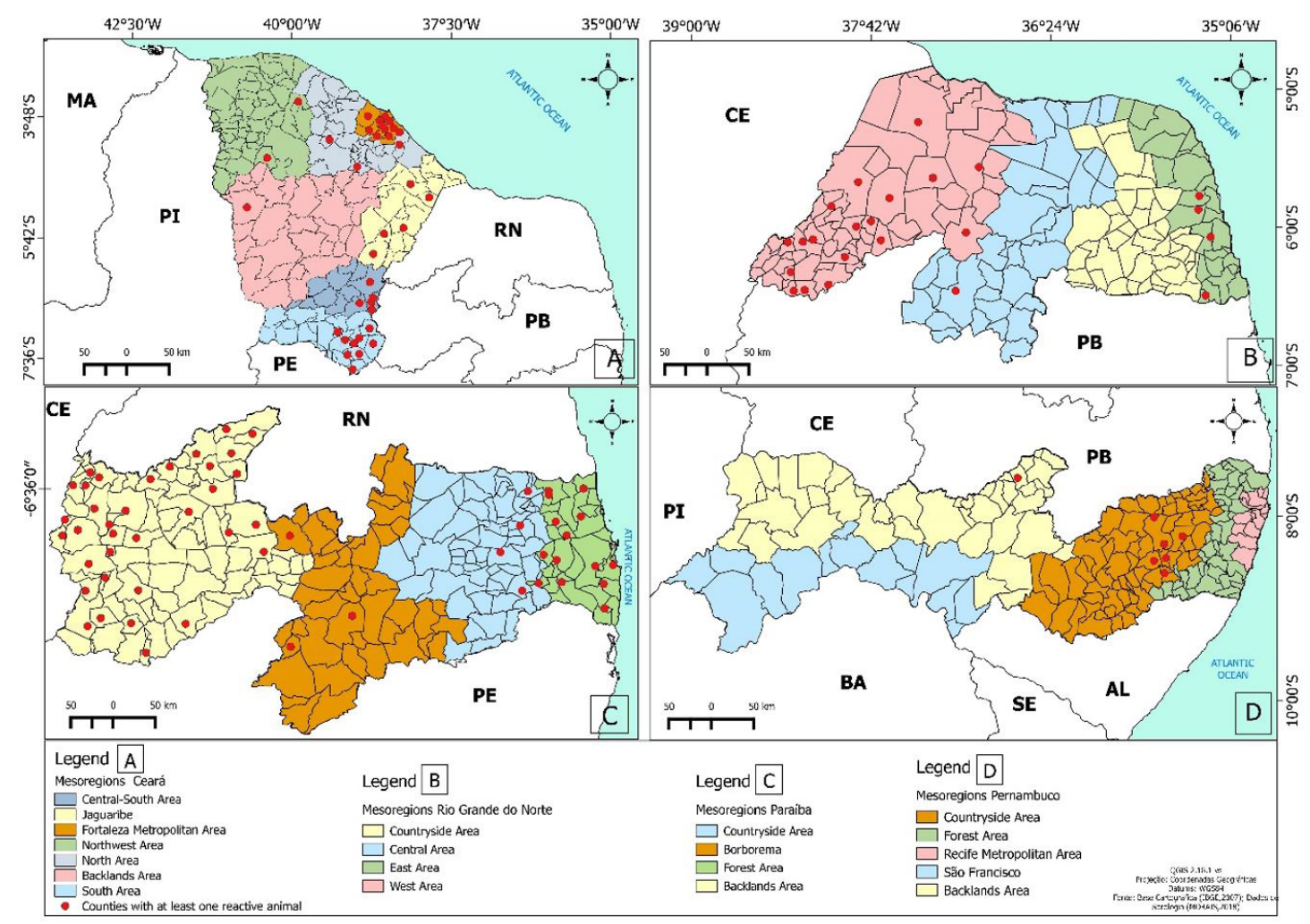

Figure 2 - Spatialization of the municipalities with at least one equine reagent to leptospirosis MAT in the states of Ceará (A), Rio Grande do Norte (B), Paraíba (C), and Pernambuco (D).

Table 2 - Distribution of MAT* titers to Leptospira antibodies in equines from municipalities of Northeast Brazil in March and April 2015 - Patos, 2019

\begin{tabular}{|c|c|c|c|c|c|}
\hline \multirow{2}{*}{ Serogroups } & \multicolumn{5}{|c|}{ Titers } \\
\hline & 100 & 200 & 400 & 800 & TOTAL (\%) \\
\hline Australis & 77 & 51 & 10 & 2 & 140 (37.2) \\
\hline Icterohaemorrhagiae & 30 & 65 & 13 & 2 & $110(29,3)$ \\
\hline Tarassovi & 16 & 17 & 3 & 0 & $36(9.6)$ \\
\hline Sejroe & 5 & 8 & 8 & 1 & $22(5.8)$ \\
\hline Pomona & 6 & 6 & 8 & 0 & $20(5.3)$ \\
\hline Grippotyphosa & 4 & 9 & 4 & 0 & $17(4.5)$ \\
\hline Pyrogenes & 5 & 4 & 0 & 0 & $9(2.4)$ \\
\hline Bataviae & 4 & 2 & 0 & 1 & $7(1.9)$ \\
\hline Ballum & 1 & 3 & 1 & 0 & $5(1.3)$ \\
\hline Hebdomadis & 2 & 1 & 2 & 0 & $5(1.3)$ \\
\hline Mini & 0 & 2 & 0 & 0 & $2(0.5)$ \\
\hline Celledoni & 1 & 0 & 0 & 0 & $1(0.3)$ \\
\hline Shermani & 1 & 0 & 0 & 0 & $1(0.3)$ \\
\hline Javanica & 0 & 1 & 0 & 0 & $1(0.3)$ \\
\hline TOTAL (\%) & $152(40.4)$ & $169(45)$ & $49(13)$ & $6(1.6)$ & $376(100)$ \\
\hline
\end{tabular}

*MAT $=$ Microscopic Agglutination Test applied to leptospirosis diagnosis. 
Table 3 - Results of the univariate analysis with the most associated variables $(P \leq 0.20)$ with seropositivity for Leptospira spp. of equine blood samples, from March to April 2015, in municipalities of Northeast Brazil, Brazil - Patos, 2019

\begin{tabular}{|c|c|c|c|c|}
\hline Variable & Category & Total of animals & Positive Animals (\%) & $P^{*}$ \\
\hline \multirow[t]{2}{*}{ Sex } & Male & 635 & $168(26.5)$ & \\
\hline & Female & 632 & $208(32.9)$ & 0.014 \\
\hline \multirow[t]{4}{*}{ Age } & 1 to 5 years old & 516 & $96(18.6)$ & \\
\hline & 6 to 10 years old & 607 & $236(38.9)$ & \\
\hline & 11 to 15 years old & 122 & $38(31.1)$ & \\
\hline & 16 to 26 years old & 22 & $6(27.3)$ & 0.001 \\
\hline
\end{tabular}

*Probability of Occurrence at Chance.

Pernambuco, respectively. There were significant statistical differences regarding sex $(\mathrm{P}=0.014)$ and age $(\mathrm{P}=0.001)$. In total, females presented with higher seroreactivity (32.9\%) when compared to males (26.5\%), and younger animals ( 1 to 5 years old) had lower seroreactivity (18.6\%) than older animals (38.9\%: 6 to 10 years old; $31.1 \%$ : 11 to 15 years old; $27.3 \%$ : 16 to 26 years old (Table 3 ).

\section{Discussion}

The frequency (29.7\%) of equines seropositive to Leptospira spp. in the present study was considered high, since they were animals destined for equestrian competition, theoretically being well cared for during rearing, although vaccination against leptospirosis was not a commonly adopted practice in the region. In addition, environmental factors that are adverse to the survival of the agent in the studied area, located in the Brazilian semiarid region, should be taken into account, as they may have negatively influenced seropositive frequency of exposed animals.

It was possible to verify a significant variation in the agglutinin titers, starting from the minimum 100 to 800 . Usually antibody titers in equines remain in the range of up to 200 (Pilgrim \& Threlfall, 1999), which also occurred in our study; $85.4 \%$ of the positive samples had titers $\leq 200$. Low titers, especially those $\leq 200$, may indicate either an adaptability to reactive serogroups or that these animals are in the chronic phase of the disease (Ellis, 2015).

The predominant serogroups in this study were Australis and Icterohaemorrhagiae, accounting for 66.5\% of the positive reactions. We also observed that when the seropositive reactions were grouped among the 16 mesoregions studied, the serogroup Australis predominated in 10 of them and Icterohaemorrhagiae in six (Table 1). Martins \& Lilenbaum (2013), analyzing studies performed in the last 20 years in Rio de Janeiro, found that the frequency of seropositivity varied between 27 and $42.9 \%$, and that the main serogroups involved in the infection were also Australis and Icterohaemorrhagiae.
The variation in the occurrence of these serogroups is determined by the presence of reservoirs as well as by abiotic factors that directly influence the occurrence of the disease (Hamond et al., 2014). However, the serogroup Australis is the most common in equidae and is seen to be well adapted to this species (Ellis, 2015). According to Pinto et al. (2017), infections caused by incidental serogroups such as Icterohaemorrhagiae usually result in acute systemic disease, but when caused by the Australis serogroup, to which equines are adapted, the infections could be subclinical.

Reactions to the Australis serogroup (37.2\%) predominated in the bordering mesoregions among the analyzed states, which are in a drought period most of the year. An exception is the Eastern Potiguar Region, where reactions were concentrated on the coast. Nevertheless, the frequency calculation in this region may have been influenced by the reduced number of cities and animals sampled (Table 1). It is worth mentioning that, although possibly adapted to equines, the serogroup Australis may still cause clinical disease in this species, and be a source of infection for other animal species (Pinna et al., 2008).

The Icterohaemorrhagiae serogroup, the second most frequent in this study (29.3\%), has been widely reported in horses in tropical areas (Lasta et al., 2013; Teixeira et al., 2014; Dias et al., 2015) and is one of the main groups responsible for infections in humans (Oliveira et al., 2017; Polo et al., 2019). The serogroup stands out because of its high prevalence in equines in Brazil, especially in studies conducted in high density demographic regions and/or coastal areas (Teixeira et al., 2014; Dias et al., 2015). In this study, the occurrence of serological reactions to Icterohaemorrhagiae serogroup was observed in larger urban centers and coastal areas, such as the metropolitan area in Fortaleza and Mata Paraibana. This can be explained by inadequate sanitary conditions, as the main reservoirs of this serogroup are rodents (Alves et al., 2018), as well as the high humidity and rainfall, which favors contact between horses and urine (Hamond et al., 2012a). 
There was higher seropositivity among females (33\%) when compared to males (26.5\%). These results reinforce the information reported by Langoni et al. (2004), Dashliboron et al. (2013), and Maleki et al. (2015), who verified that $61.4 \%$, $58.3 \%$, and $87.5 \%$, respectively, of positive reactions in their studies were females $(\mathrm{P}<0.05)$. The greater frequency in mares can be attributed to the different management of females and males (Langoni et al., 2004). A possible hypothesis is that most male equines, especially those destined for sport, are castrated to make them more docile (Finger et al., 2011), are excluded from reproductive management, and when whole, most of the time are trained intensively, which reduces their contact with other groups and the possibility for contamination (Ellis, 1994). In turn, females are usually managed in large groups and actively participate in the reproductive sector of the estates.

We observed a higher frequency in animals older than six years when compared to younger ones ( 1 to 5 years old), a finding that coincides with Rocha et al. (2004), who attributed this higher occurrence to the longer exposure time of older equines to Leptospira spp. in the environment. The highest frequency of seropositive animals (38.9\%) occurred in equines that were in the second age category (6-10), and in the older age group, the frequency tended to decrease to $27.3 \%$, which can be attributed to a possible adaptation of the species to the serogroups to which they had been exposed throughout their lives. Dashliboron et al. (2013) found a significant relationship between aging and the prevalence of leptospiral infection ( $\mathrm{P}<0.05) ; 4.87 \%$ for equines aged 1 to 3 years old, 20\% for the 3-6 years old and 6-9 years old, and $0 \%$ in the group with animals older than 9.

Taking into account the significant level of occurrence of the Icterohaemorrhagiae incidental serogroup, it is important to analyze how the animals come into contact with rodents and how to proceed with the implementation of rodent control (Verma et al., 2013), adequate sealing of waste and waste depot sites, as well as periodic cleaning of feeders and drinkers used by the animals (Alves et al., 2016). However, for infections of the Australis serogroup, control becomes more complex, since the main form of transmission is intraspecies infection (Ellis, 2015). General measures are indicated, such as avoiding conglomerations of animals and managing them in groups according to age and sex, allowing only the import of animals proven to be seronegative or who had been quarantined, monitoring of seropositive animals, correct disposal of sewage, placental, and abortion remains, and hygienic use of zootechnical equipment.

\section{Conclusion}

The results of this study allowed visualization of the extent and distribution of leptospirosis infection in equines in the Brazilian Northeast region, as well as the most reagent serogroups. Intraspecies transmission seems to be the main route of dissemination of the disease in equines, although rodents are still important sources of infection. The introduction of hygienic-sanitary measures is suggested, as well as management of the animals in groups according to sex and age.

\section{Conflict of Interest}

The authors state that they have no conflicts of interest to declare.

\section{Ethics Statement}

The article was approved by the Research Ethics Committee (CEP) of the Center for Health and Rural Technology from the Federal University of Campina Grande (CSTR/UFCG) under No. 085/2017, and it was carried out in accordance with the technical standards for biosafety and ethics.

\section{Acknowledgements}

National Council for Scientific and Technological Development (CNPQ) for the research grant. Veterinary Laboratory Diagnostics, Ltd. for providing equine sera, and Communicable Disease Laboratory (CFU) and its members for all assistance and support in the diagnostic analyses and in the preparation of the article.

\section{References}

Alves JRA, Oliveira KDS, Costa DF, Fernandes LG, Higino SSS, Alves CJ, Santos CSAB, Azevedo SS. Epidemiological characterization of leptospirosis in horses in the state of Pernambuco, northeastern Brazil. Arq Inst Biol. 2016;83(1):15. http://dx.doi.org/10.1590/1808-1657001032014.
Alves LB, Medeiros RB, Silva CA, Berezuk AG. The relationship between leptospirosis, rains and government actions at Mato Grosso do Sul state - Brazil. Rev Eletrônica Ass Geo Bra. 2018;14(28):1-18. 
Araújo SMS. A região semiárida do nordeste do Brasil: questões ambientais e possibilidades de uso sustentável dos recursos. Rev Cien FASETE, 2011;5(5):89-98.

Artiushin SC, Timoney JF, Balasuriya UB, Erol E, Sells SF. Real-time PCR for detection of Leptospira interrogans serovar Pomona type kennewicki in equine clinical specimens. J Equine Vet Sci. 2012;32(10):53. http://dx.doi.org/10.1016/j. jevs.2012.08.117.

Ayres M, Ayres M Jr, Ayres DL, Santos AS. Bioestat 5.0 Aplicações estatísticas nas áreas das ciências biomédicas. Belém: ONG Mamiraua; 2007. p. 1-364.

Braga J, Hamond C, Martins M, Abreu RN, Lilenbaum W. Ophthalmic alterations in horses with leptospirosis by serovar Icterohaemorrhagiae in Rio de Janeiro, Brazil. Pesq Vet Bras. 2011;31(2):147-50. http://dx.doi.org/10.1590/ S0100-736X2011000200009.

Caselani K, Oliveira PR, Ferraudo AS, Lima-Ribeiro AMC, Gírio RJS. Leptospirosis seroepidemiological study in horses used for urban traction. Rev Inst Adolfo Lutz. 2012;71(3):582-7. http://dx.doi.org/10.2012/issn-3821-7303.

Coelho EGA, Oliveira DAA. Testes genéticos na equideocultura. Rev Bras Zootec. 2008;37(1):202-5. http://dx.doi.org/10.1590/ S1516-35982008001300023.

Dashliboron OJ, Hassanpour A, Abdollahpour GR. Serological study of leptospirosis in horses in Gonbad, Iran. Glob Vet. 2013;10(1):51-4. http://dx.doi.org/10.5829/ idosi.gv.2013.10.1.71122.

Dias HLT, Santos WRR, Lima PDL, Araújo CV, Negrão AMG, Vasconcellos SA. Inquérito sorológico para leptospirose em condutores de carroças e equídeos de tração em Belém, Pará. Rev Ciênc Agrár. 2015;58(4):396-401. http://dx.doi. org/10.4322/rca.2013.

Ellis WA. Animal leptospirosis. Current Top in Microb and Immun. 2015;387(1):99-137.

Ellis WA. Leptospirosis as cause of reproductive failure. Vet Clin of North America: Food and Animal Practice. 1994;10(1):463-78.

Finger MA, Dornbusch PT, Bonfá AF, Dornbusch LPTC, Deconto I, Filho IRB. Comparison of two techniques in equine orchiectomy, employed in the instruction of the veterinary surgical technique. Arch Vet Sci. 2011;16(3):539. http://dx.doi.org/10.5380/avs.v16i3.20540.
Hamond C, Martins G, Lawson FR, Medeiros MA, Lilenbaum $\mathrm{W}$. The role of horses in the transmission of leptospirosis in an urban tropical area. Epidemiol Infect. 2012b;15(1):1-3. http:// dx.doi.org/10.1017/S0950268812000416. PMid:22417781.

Hamond C, Martins G, Lilenbaum W. Subclinical leptospirosis may impair athletic performance in racing horses. Trop Anim Health Prod. 2012a;44(8):1927-30. http://dx.doi. org/10.1007/s11250-012-0158-5. PMid:22547110.

Hamond C, Pinna A, Martins G, Lilenbaum W. The role of leptospirosis in reproductive disorders in horses. Trop Anim Health Prod. 2014;46(1):1-10. http://dx.doi.org/10.1007/ s11250-013-0459-3. PMid:23990441.

Hashimoto VY, Gonçalves DD, Silva FG, Oliveira RC, Alves LA, Reichmann P, Muller EE, Freitas JC. Occurrence of antibodies against Leptospira spp. in horses of the urban area of Londrina, Paraná, Brazil. Rev Inst Med Trop. 2007;49(5):327-30. http://dx.doi.org/10.1590/S003646652007000500010. PMid:18026641.

Langoni H, Silva AV, Pezerico SB, Lima VY. Anti-leptospire Agglutinins in Equine Sera, from São Paulo, Goias, and Mato Grosso do Sul, Brazil, 1996-2001. J of Venom Animals and Tox Includ Trop Diseas. 2004;10(3):207-18. http://dx.doi. org/10.1590/S1678-91992004000300003.

Lasta CS, Oliveira ST, Merini LP, Dasso MG, Pedralli V, González FHD. Anti-Leptospira agglutinins in horses in Porto Alegre city, Brazil. Rev Bras Cienc Vet. 2013;20(1):235. http://dx.doi.org/10.4322/rbcv.2014.051.

Lima RAS, Cintra AG. Revisão do estudo do complexo do agronegócio do cavalo. Brasília: Câmara de Equideocultura do Ministério da Agricultura, Pecuária e Abastecimento; 2016. 56 p.

Maleki S, Sookhtehzari A, Abdollahpour G, Rahnein M. Seroepidemiologic Study of Horses Leptospirosis in Khorramabad, west Iran. Bul Tekn Tanam. 2015;12(1):1358. http://dx.doi.org/10.1590/0001-3765201421565973.

Martins G, Lilenbaum W. The panorama of animal leptospirosis in Rio de Janeiro, Brazil, regarding the seroepidemiology of the infection in tropical regions. BMC Vet Res. 2013;9(1):237. http://dx.doi.org/10.1186/17466148-9-237. PMid:24289165.

OIE: Organização Mundial de Saúde Animal. Manual of diagnostic Tests and vacines for Terrestrial Animals, Paris: 
World Organization for Animal Health; 2014. Chapter 3.1.12, Leptospirosis.

Oliveira MAA, Leal ÉA, Correia MA, Serufo Filho JC, Dias RS, Serufo JC. Human leptospirosis: occurrence of serovars of Leptospira spp. in the state of Minas Gerais, Brazil, from 2008 to 2012. Braz J Microbiol. 2017;4(8):483-8. http:// dx.doi.org/10.1016/j.bjm.2016.12.010. PMid:28365095.

Pilgrim S, Threlfall WR. A serologic study of leptospirosis in 20 mares. Vet Clin N Am-Equine. 1999;21(1):20-3

Pinna MH, Varges R, Lilenbaum W. Application of an integrated program of leptospirosis control in horses from Rio de Janeiro, Brazil. Rev Bras Cienc Vet. 2008;15(2):63-6. http://dx.doi.org/10.4322/rbcv.2014.199.

Pinto PS, Libonati H, Lilenbaum W. A systematic review of leptospirosis on dogs, pigs, and horses in Latin America. Trop Anim Health Prod. 2017;49(2):231-8. http://dx.doi. org/10.1007/s11250-016-1201-8. PMid:27909915.

Polo N, Machado G, Rodrigues R, Nájera Hamrick P, MunozZanzi C, Pereira MM, Bercini M, Timm LN, Schneider MC. A one health approach to investigating Leptospira serogroups and their spatial distributions among humans and animals in Rio Grande do Sul, Brazil, 2013-2015. Trop Med Infect Dis. 2019;4(42):1-20. http://dx.doi.org/10.3390/ tropicalmed4010042. PMid:30818803.

Rocha T, Ellis WA, Montgomery J, Gilmore C, Regalla J, Brem S. Microbiological and serological study of leptospirosis in horses at slaughter: first isolations. Vet Sci. 2004;76(3):199-202. http://dx.doi.org/10.1016/j.rvsc.2003.12.003. PMid:15046953.

Sellon DC, Long MT. Equine infectious diseases. Saint Louis: Elsevier; 2007. 664 p.
SINAN: Sistema de Informação de Agravos de Notificação. Leptospirose-banco de dados [Internet]. Brasília: SINAN; 2018 [cited 2019 Dec 4]. Available from: http://portalsinan. saude.gov.br/leptospirose.

Teixeira G, Sarmento LC, Silva ECP, Silva MB, Abreu DRO, Hélio SL. Aspectos clínicos e levantamento sorológico da leptospirose em equídeos de carga do município de Marechal Deodoro, estado de Alagoas, Brasil. Ciênc Vet Tróp. 2014;17(3):19.

Verma A, Stevenson B, Adler B. Leptospirosis in horses. Vet Microbiol. 2013;167(1):6-66. http://dx.doi.org/10.1016/j. vetmic.2013.04.012. PMid:23647816.

Financial Support: The authors thank Conselho Nacional de Desenvolvimento Científico e Tecnológico (CNPq), for the financial support (number 302222/2016-2).

Authors Contributions: Davidianne de Andrade Morais participated in the planning, serology, analysis and spatialization of the results, and elaboration of the scientific text. Camila de Sousa Bezerra participated in the planning and serology. Denize Monteiro dos Anjos participated in the analysis and spatialization of the results. Bruno Cesar Nunes participated in the serology and revision of the manuscript. Denise Batista Nogueira participated in the serology. Nebson Fernandes Pequeno provided the serological samples. Diego Figueiredo da Costa participated in the serology and revision of the manuscript. Severino Silvano dos Santos Higino participated in the review of the manuscript. Sérgio Santos Azevedo participated in the planning, analysis of the results and in the review of the manuscript. Clebert José Alves participated in the planning, analysis of the results, elaboration and review of the scientific text. 